\title{
Knowledge of doctors and nurses on pain in patients undergoing craniotomy
}

\author{
Maria do Carmo de Oliveira Ribeiro ${ }^{1}$ \\ Carlos Umberto Pereira ${ }^{2}$ \\ Ana Maria Calil Sallum ${ }^{3}$ \\ José Antonio Barreto Alves ${ }^{1}$ \\ Marcelly Freitas Albuquerque ${ }^{4}$ \\ Paula Akemi Fujishima ${ }^{4}$
}

\begin{abstract}
The study objectives were to characterize the profile of the doctors and nurses caring for patients in the craniotomy postoperative period, checking pain assessment methods and to identify the existence of analgesia protocols. Cross-sectional and analytical study. The casuistry is constituted of 30 doctors and 30 nurses. The results revealed that $83.3 \%$ of the nurses were female, $63.3 \%$ knew pain scales, and $16.6 \%$ said that analgesia protocols exist. Regarding doctors $60 \%$ were male, $70 \%$ knew the pain scales, 3.3\% had specialization in pain treatment, $13.3 \%$ they stated that there are analgesia protocols. The ignorance on the part of doctors and nurses about the assessment scales and pain assessment methods reveals the need for the creation of institutional policies on controlling pain, the use of instruments for the measurement of the pain phenomenon and analgesia protocols in the institution.
\end{abstract}

Descriptors: Pain; Pain Measurement; Nursing; Craniotomy.

${ }^{1}$ Doctoral Student, Assistant Professor, Universidade Federal de Sergipe, Brazil.

2 PhD, Adjunct Professor, Departamento de Medicina, Universidade Federal de Sergipe, Brazil.

${ }^{3}$ PhD, Consultant in Pain, Hospital Sírio Libanês, Brazil.

${ }^{4} \mathrm{RN}$.

Corresponding Author:

Maria do Carmo de Oliveira Ribeiro

Universidade Federal de Sergipe. Departamento de Enfermagem

Av. Marechal Rondon, $s / n$

Jardim Rosa Elze

CEP 49100-000, São Cristóvão, SE, Brasil

E-mail: enffer2@yahoo.com.br 


\section{Conhecimento de médicos e enfermeiros sobre dor em pacientes submetidos à craniotomia}

Objetivos: caracterizar o perfil dos médicos e enfermeiros que cuidam de pacientes em pósoperatório de craniotomia, verificar métodos de avaliação da dor e identificar a existência de protocolos de analgesia. Método: este é um estudo transversal e analítico. A casuística constitui-se por 30 médicos e 30 enfermeiros. Resultados: 83,3\% dos enfermeiros era composto por mulheres, $63,3 \%$ conheciam escalas de dor e $16,6 \%$ afirmaram existir protocolos de analgesia. Quanto aos médicos, 60\% pertenciam ao sexo masculino, 70\% conheciam as escalas de dor, 3,3\% possuíam especialização em tratamento da dor, 13,3\% afirmaram existir protocolos de analgesia. Conclusão: o desconhecimento dos médicos e enfermeiros a respeito das escalas de avaliação e métodos de avaliação da dor revela a necessidade da criação de políticas institucionais sobre o controle da dor, uso de instrumentos de mensuração do fenômeno doloroso e protocolos de analgesia na instituição.

Descritores: Dor; Medição da Dor; Enfermagem; Craniotomia.

\section{Conocimiento de médicos y enfermeros sobre dolor en pacientes sometidos a la craniotomia}

Objetivos: caracterizar el perfil de los médicos y enfermeros que cuidan a pacientes en postoperatorio de craniotomia, verificar métodos de evaluación del dolor e identificar la existencia de protocolos de analgesia. Método: estudio transversal y analítico. La casuística se constituye por 30 médicos y 30 enfermeros. Resultados: 83,3\% de los enfermeros eran del sexo femenino, $63,3 \%$ conocían escalas de dolor, y $16,6 \%$ afirmaron existir protocolos de analgesia. En cuanto a los médicos $60 \%$ eran del sexo masculino, $70 \%$ conocían las escalas de dolor, 3,3\% poseía especialización en tratamiento del dolor, 13,3\% afirmaron existir protocolos de analgesia. Conclusión: el desconocimiento de los médicos y enfermeros a respeto de las escalas de evaluación y métodos de evaluación del dolor revela la necesidad de la creación de políticas institucionales sobre el control del dolor, uso de instrumentos de mensuración del fenómeno doloroso y protocolos de analgesia en la institución.

Descriptores: Dolor; Dimensión del Dolor; Enfermería; Craneotomía.

\section{Introduction}

Pain is one of the most intimate and subjective sensory and emotional experience of an unpleasant character associated with actual or potential tissue damage $^{(1)}$. It is also defined as the fifth vital sign, and, therefore, must be evaluated after the measurement of temperature, pulse, respirations and arterial pressure. The complaint of pain by the patient should always be considered and valued since this is an individual and intra-transferable experience. In patients undergoing craniotomy pain is most commonly found as a headache characterized as moderate to severe ${ }^{(1-3)}$.

Pain is one of the leading causes of morbidity in the world, with an estimated prevalence of up to $79 \%$ in Europe. Pain affects between $19 \%$ and $50 \%$ of Europeans and this prevalence increases with age. It is noteworthy that among the forms of pain, migraine is considered a public health problem that causes physical discomfort and disability in the patients ${ }^{(3-5)}$. A study ${ }^{(6)}$ performed on postoperative craniotomy pain found an incidence of pain in $93 \%$ of the population studied, with moderate to severe intensity pain being higher between the first and third postoperative day.

Intense pain can negatively influence patient outcomes, delaying their recovery. Effectively treating postoperative pain contributes to the maintenance of the physiological functions, avoids harmful side effects resulting from the pain, allows a shorter hospital stay and lower costs, and provides greater comfort and satisfaction to the patient ${ }^{(7-8)}$. It is noteworthy that pain is also considered as one of the main stressors that affect the quality of life of patients, therefore, inappropriate treatment remains a critical problem in hospitalized patients. In contrast, the appropriate evaluation and treatment of pain improves the quality of life of the patients ${ }^{(9)}$. 
Nurses are professionals who spend the majority of their time caring for patients, therefore they have a vital role in the appropriate management of pain, particularly in patients undergoing cranial surgery ${ }^{(10)}$. In this context, the motivation for this study emerged with the following guiding questions: What is the profile of physicians and nurses who care for patients in the elective craniotomy postoperative period? What forms of evaluation and treatment of pain are used by these professionals? Do analgesia protocols exist in the institutions investigated?

The aims of this study were to characterize the profile of the physicians and nurses who care for postoperative craniotomy patients, to verify the methods of pain assessment, and to identify the existence of analgesia protocols in the institution investigated. It is hoped that the results of this study may sensitize the managers and professionals of the healthcare area regarding the appropriate control of postoperative pain, since the appropriate management of this is a patient's right and a humanitarian aspect of treatment.

\section{Method}

This is a cross-sectional analytical study conducted in the Fundação de Beneficência Surgical Hospital (FBHC), located in Aracaju, Sergipe, Brazil, during the period from March to April 2011. Data collection took place after approval by the Research Ethics Committee of the Federal University of Sergipe, under protocol No. CAAE2678.0.000.107-10, conforming to the disciplinary rules of Resolution No. 196 of October $10^{\text {th }} 1996$, of the Ministry of Health, National Health Council (CONEP/Brazil).

The study sample consisted of 30 physicians and 30 nurses who met the following inclusion criteria: to be working in the Intensive Care, Neurosurgery or Semiintensive Units of the institution studied and to agree to participate. All participants signed the Terms of Free Prior Informed Consent (TFPIC), in which the subjects were guaranteed confidentiality and that the results would only be used for academic purposes. The data collection form consisted of information regarding the characterization of these professionals, the means they use to identify the pain of the patient, clinical manifestations caused by the pain, knowledge about the pain evaluation scales, medication used for mild, moderate and severe pain and analgesia protocols, with the completion of the data performed in the presence of the researcher.

The data were stored in a computerized database using the Statistical Package for the Social Sciences (SPSS) version 20.0 software, descriptive and inferential statistical analysis was conducted and presented in table form. To investigate the relationship between the variables the chi-square and Fisher's exact tests were used, assuming a significance level of $5 \%$.

\section{Results}

A total of 60 healthcare professionals, 30 nurses and 30 physicians, were studied. It was observed that the majority of the nurses, $25(83.3 \%)$, were female, of whom $10(33.3 \%)$ had more than 10 years since their graduation, $18(60 \%)$ had graduated from public universities, 14 $(46.6 \%)$ worked in the intensive care unit and only 3 $(10 \%)$ were specialists in this area. It is noteworthy that none of the nurses were pain treatment specialists.

In relation to the physicians, $18(60 \%)$ of them were male, 15 (50\%) presented more than 10 years since their graduation, 27 (90\%) had graduated from public universities, $18(60.0 \%)$ worked in the intensive care unit, $14(46.6 \%)$ had less than 3 years experience caring for postoperative craniotomy patients and only one $(3.3 \%)$ was a pain treatment specialist (Table 1 ).

Table 1 - Profile of the physicians and nurses who care for postoperative craniotomy patients, FBHC, Aracaju, SE, Brazil, 2011

\begin{tabular}{|c|c|c|c|c|c|}
\hline \multirow{2}{*}{ Variable } & \multicolumn{2}{|c|}{ Physicians } & \multicolumn{2}{|c|}{ Nurses } & \multirow{2}{*}{$\mathrm{p}$-value } \\
\hline & $(n=30)$ & $\%$ & $(n=30)$ & $\%$ & \\
\hline \multicolumn{6}{|l|}{ Gender } \\
\hline Female & 12 & $40 \%$ & 25 & $83.3 \%$ & \\
\hline Male & 18 & $60 \%$ & 5 & $16.6 \%$ & 0.001 \\
\hline \multicolumn{6}{|l|}{$\begin{array}{l}\text { Time since } \\
\text { graduation (years) }\end{array}$} \\
\hline Less than 5 years & 7 & $23.3 \%$ & 17 & $56.6 \%$ & 0.02 \\
\hline 5 to 10 & 8 & $26.6 \%$ & 3 & $10 \%$ & \\
\hline More than 10 & 15 & $50 \%$ & 10 & $33.3 \%$ & \\
\hline \multicolumn{6}{|l|}{ University } \\
\hline Public & 27 & $90 \%$ & 18 & $66.6 \%$ & 0.008 \\
\hline Private & 3 & $10 \%$ & 12 & $33.3 \%$ & \\
\hline \multicolumn{6}{|l|}{ Area of work } \\
\hline Intensive Care & 18 & $60 \%$ & 14 & $43.3 \%$ & 0.01 \\
\hline Neurosurgery & 5 & $16.6 \%$ & 0 & & \\
\hline Varied & 7 & $23.3 \%$ & 16 & $56.6 \%$ & \\
\hline \multicolumn{6}{|l|}{ Specialization } \\
\hline Intensive Care & 12 & $40 \%$ & 3 & $10 \%$ & 0.001 \\
\hline Neurosurgery & 4 & $13.3 \%$ & 0 & & \\
\hline Other & 4 & $13.3 \%$ & 16 & $53.3 \%$ & \\
\hline Pain treatment & 1 & $3.3 \%$ & 0 & & \\
\hline None & 9 & $30 \%$ & 11 & $36.6 \%$ & \\
\hline \multicolumn{6}{|l|}{$\begin{array}{l}\text { Time (years) with } \\
\text { craniotomy patients }\end{array}$} \\
\hline Less than 3 years & 14 & $46.6 \%$ & 24 & $80 \%$ & 0.02 \\
\hline 4 to 10 & 6 & $20 \%$ & 3 & $10 \%$ & \\
\hline More than 10 & 10 & $33.3 \%$ & 3 & $10 \%$ & \\
\hline
\end{tabular}

Fisher Test 
Regarding the methods used by these professionals for the evaluation of pain, the study showed that these professionals identify pain through the following neurovegetative alterations: tachycardia, nausea and vomiting, decreased immune system, hyperglycemia and reduced intestinal tone. It should be noted that 30 (100\%) of the physicians and 27 (90\%) of the nurses responded that the main manifestation of pain was tachycardia. No professional mentioned the decrease in oxygen saturation. As regards the pain evaluation scales, $21(70 \%)$ of the physicians and $19(63.3 \%)$ of the nurses knew the scales. This highlights that 9 (30\%) of the physicians and $11(36.6 \%)$ of the nurses were unaware of the pain scales.

Table 2 presents the knowledge of the physicians and nurses on the use of analgesics recommended by the World Health Organization (WHO). There was also a statistically significant difference for the variable severe pain $\mathrm{p}<0.001$.

Concerning the medication used for mild pain, 29 (96.6\%) physicians and $26(86.6 \%)$ nurses said that for this type of pain simple analgesics should be used. In relation to moderate pain, it was found that only 16 (53.3\%) physicians and nine (30\%) nurses reported that weak opioids should be used. Finally, 26 (86.6\%) physicians and 14 (46.6\%) nurses reported that strong opioids should be used for severe pain and none of the professionals mentioned the analgesic ladder recommended by the WHO.

Table 2 - Knowledge regarding the use of analgesics recommended by the WHO, FBHC, Aracaju, SE, Brazil, 2011

\begin{tabular}{|c|c|c|c|c|c|}
\hline \multirow{2}{*}{ Medication } & \multicolumn{2}{|c|}{ Physicians } & \multicolumn{2}{|c|}{ Nurses } & \multirow{2}{*}{ p-value } \\
\hline & $(n=30)$ & $\%$ & $(n=30)$ & $\%$ & \\
\hline \multicolumn{6}{|l|}{ Mild pain } \\
\hline Knew & 29 & 96.6 & 26 & 86.6 & 0.160 \\
\hline Did not know & 1 & 3.3 & 4 & 13.3 & \\
\hline \multicolumn{6}{|l|}{ Moderate pain } \\
\hline Knew & 16 & 53.3 & 9 & 30.0 & 0.070 \\
\hline Did not know & 14 & 46.6 & 21 & 70.0 & \\
\hline \multicolumn{6}{|l|}{ Severe pain } \\
\hline Knew & 26 & 86.6 & 14 & 46.6 & 0.001 \\
\hline Did not know & 4 & 13.3 & 16 & 53.4 & \\
\hline
\end{tabular}

The knowledge of physicians and nurses regarding pain treatment is demonstrated in Table 3. In relation to the pharmacological treatment $100 \%$ of the physicians and nurses demonstrated knowledge, however, in relation to non-pharmacological treatments it was found that $19(63.3 \%)$ of the physicians and $15(50 \%)$ of the nurses had no knowledge about distraction and relaxation, while 28 (93.3\%) of the physicians and 29 $(96.6 \%)$ of the nurses had no knowledge about guided imagery.

Table 3 - Knowledge of the pain treatment methods, FBHC, Aracaju, SE, Brazil, 2011

\begin{tabular}{lccccc}
\hline & \multicolumn{2}{c}{ Physicians } & & \multicolumn{2}{c}{ Nurses } \\
\cline { 2 - 3 } \cline { 5 - 6 } & $(\mathbf{n}=\mathbf{3 0})$ & $\%$ & & $(\mathbf{n}=\mathbf{3 0})$ & $\%$ \\
\hline $\begin{array}{l}\text { Pharmacological treatment } \\
\quad\end{array}$ & 30 & 100 & & 30 & 100 \\
$\quad$ Yes & 0 & & & 0 & \\
$\quad$ No & & & & & \\
Patient Controlled Analgesia & & & & & \\
$\quad$ Yes & 17 & 56.6 & & 11 & 36.6 \\
No & 13 & 43.3 & & 19 & 63.3 \\
Distraction and relaxation & & & & & \\
$\quad$ Yes & 11 & 36.6 & & 15 & 50 \\
$\quad$ No & 19 & 63.3 & & 15 & 50 \\
Guided imagery & & & & \\
$\quad$ Yes & 2 & 6.6 & & 1 & 3.3 \\
$\quad$ No & 28 & 93.3 & & 29 & 96.6 \\
\hline
\end{tabular}

Regarding the differences between analgesia and sedation, $26(86.6 \%)$ of the physicians and 12 (40\%) of the nurses knew how to differentiate between them. The chi-square test showed $p<0.0001$. (Table 4).

Table 4 - Differences between sedation and analgesia, described by physicians and nurses, FBHC, Aracaju, SE, Brazil, 2011

\begin{tabular}{|c|c|c|c|c|c|}
\hline \multirow{2}{*}{$\begin{array}{c}\text { Difference between } \\
\text { analgesia and } \\
\text { sedation }\end{array}$} & \multicolumn{2}{|c|}{ Physicians } & \multicolumn{2}{|c|}{ Nurses } & \multirow{2}{*}{$p$-value } \\
\hline & $(n=30)$ & $\%$ & $(n=30)$ & $\%$ & \\
\hline $\begin{array}{l}\text { Knew how to } \\
\text { differentiate }\end{array}$ & 26 & 86.6 & 12 & 40.0 & \\
\hline $\begin{array}{l}\text { Did not know how to } \\
\text { differentiate }\end{array}$ & 4 & 13.3 & 18 & 60.0 & $<0.0001$ \\
\hline
\end{tabular}

Chi-square test $p=0.05$

Considering the concept of pain, $19(63.3 \%)$ of the physicians and 12 (40\%) of the nurses reported an adequate pain concept. Regarding the existence of analgesia protocols in the institution, it was identified that only $4(13.3 \%)$ of the physicians and $5(16.6 \%)$ of the nurses said that they existed.

\section{Discussion}

The complexity of postoperative craniotomy patient care demonstrates the need for a multidisciplinary approach, considering that after the surgery pain may 
be present and physicians and nurses must intervene early to prevent adverse effects due to this pain. Concerning the profile of physicians and nurses who treat postoperative craniotomy pain, it was identified that the majority of the respondents were female. It is believed that because nursing has historically been a female profession, a high frequency of this gender was found in the present study. The results show that only $3.3 \%$ of the professionals had expertise in pain treatment, and this data reveals the lack of knowledge that is extremely important in the field of practice of these professionals, in which the majority of patients frequently feel pain.

Among the professionals surveyed, $50 \%$ of the physicians and $33.3 \%$ of the nurses had more than 10 years since their graduation. This finding suggests that professionals who have worked longer have more experience and knowledge about the aspects inherent to the pain phenomenon. It was not possible to make an association between professional experience and knowledge of pain. The results reveal that among the main clinical manifestations of pain, tachycardia was the most mentioned. Pain causes facial expression of intense discomfort, psychomotor agitation, anxiety, sleep disorders, hypertension, tachycardia, increased breathing pattern, drop in oxygen saturation, hyperglycemia, nausea and vomiting, decreased immune defenses, decreased intestinal tone, and neurological and thromboembolic complications ${ }^{(1,3,11)}$. None of the professionals mentioned the decrease in oxygen saturation as an indicator of alterations found in patients with pain, which is worrying, considering that a decrease in saturation is one of the warning signs of the presence of pain. Postoperative pain is one of the most challenging clinical problems for physicians and nurses and should be constantly evaluated to avoid suffering and physiological alterations ${ }^{(12-13)}$.

This study reveals that $30 \%$ of the physicians and $36.6 \%$ of the nurses showed a lack of knowledge regarding the pain scales. These are used to determine the degree of pain that a patient is experiencing and may be unidimensional or multidimensional. The unidimensional scales evaluate only one dimension of the painful experience, the most used are: the Visual Numeric Scale (VNS) and Visual Analogue Scale (VAS). The multidimensional scales, due to their increased complexity and difficulty of application, have their use restricted to specific situations ${ }^{(1)}$. The evaluation of pain using unidimensional or multidimensional instruments should be part of the service, due to these being tools based on behavioral evidence of pain, which therefore support better care and the consequent targeting of practices. However, no scale, or even the combination of two or three, can replace the patient's report of pain, as pain is a subjective phenomenon ${ }^{(1)}$.

Regarding the knowledge of analgesia for pain treatment, the data obtained in this study differ from what is recommended by the $\mathrm{WHO}^{(14)}$, which recommends the use of the Analgesic Ladder for choosing the appropriate therapeutic treatment. According to the Analgesic Ladder, for mild pain non-opioid analgesics or non-steroidal anti-inflammatory drugs (NSAIDs) should be used. For moderate pain, the ladder recommends a weak opioid and for intense pain, the use of strong opioids, in addition or not to the non-opioid or NSAIDs analgesics. In this context, in all the degrees of intensity and from the beginning of the treatment adjuvant drugs should be used. It is noteworthy that opioid analgesics are the main pharmacological intervention for pain control in hospitalized patients. These medications provide pain relief, solve the sleep disorder arising from the pain and, consequently, improve the quality of life of patients. Although these medications present many benefits, they can cause involuntary sedation and respiratory depression. The nurse plays an important role in preventing the adverse effects of these medications through the continuous monitoring and evaluation of the patients ${ }^{(15-16)}$. Another pain treatment method is multifocal combination therapy that offers the potential to improve the efficacy and/or tolerability and safety compared to analgesia as a single agent. This combination has demonstrated efficacy with various of states of pain, including post-craniotomy pain ${ }^{(17-18)}$.

In the present study, the professionals were found to have greater knowledge regarding the pharmacological treatments compared to the alternatives. Pain management can be divided into pharmacological and non-pharmacological interventions. Non-pharmacological therapies can be used in pain relief with clinical and surgical patients(19-20). Differing from the results of this study, a study ${ }^{(21)}$ that evaluated the knowledge of physicians and nurses about pain, found that these professionals had a homogeneous and diffusely based concept regarding pain treatment.

The present study found that $86.6 \%$ of the physicians and $40 \%$ of the nurses knew how to differentiate between analgesia and sedation. Analgesia is the elimination of sensitivity to the pain without suppression of the other sensory properties and without loss of consciousness, while sedation is distinguished by 
its anxiolytic and hypnotic actions, eliminating agitation, anxiety and causing amnesia, but with little analgesic $\operatorname{activity}^{(21)}$. The findings of the present study reveal the need for training these professionals with regards to sedation and analgesia in patients undergoing craniotomy, considering that patients under sedation may remain in pain, which can impair the neurological evolution. It can be inferred that misconceptions regarding the effects of sedation and analgesia, can collaborate so that painful procedures are performed improperly, producing discomfort and distress in the patients.

The knowledge of the professionals about the definition of pain reveals that only $63.3 \%$ of the physicians and $40 \%$ of the nurses reported the pain concept correctly. For more than two decades the concept of pain has been defined by the International Association for the Study of Pain(1), however, the lack of knowledge on the part of the professionals interviewed is worrying, considering that for an adequate evaluation of pain it is also necessary for these professionals to have knowledge of the concept and its subjective aspects.

The existence of few analgesia protocols was identified in this study. Many healthcare professionals fail to recognize the intensity of the pain in the patients due to the underevaluation of the pain ${ }^{(22)}$. The inadequate evaluation of the painful phenomenon causes the pain to be misinterpreted or underestimated and therefore prejudices the appropriate management of the algic process and the quality of life of the patient ${ }^{(23)}$. It is important to highlight that physicians and nurses who care for patients undergoing craniotomy should have knowledge about the evaluation and treatment of the painful phenomenon and should use multidisciplinary strategies for the appropriate management of pain(24). It should also be noted that it is necessary that these professionals understand pain as a whole and see the patient as a unique person with their own characteristics $^{(25)}$.

\section{Conclusion}

The study on the knowledge of physicians and nurses regarding pain in patients undergoing craniotomy provided the following conclusions: only one professional was a specialist in pain management, there were few analgesia protocols and there was a lack of knowledge on the part of professionals in relation to the pain evaluation methods and scales. The insignificant number of professionals with expertise in pain is a really disturbing aspect, as knowledge about pain is of fundamental importance in carrying out the anamnesis and evaluation of the pain. It is believed that the professional who is trained in the pain area will be better able to perform the management of the painful phenomenon adequately and, consequently, to reduce the suffering of the patient.

The data reveal the need to develop institutional policies regarding pain control, the use of instruments for measuring painful phenomenon, analgesia protocols and in-service education. It is believed that the results of this study may contribute to the sensitization of health professionals concerning the importance of pain control. Additional studies are suggested, in order to further investigate the issue.

\section{References}

1. International Association for Study of Pain (IASP). Consensus development conference statement: the integrated approach to the management of pain. Accid Emerg Med. 1994;6 (document number -491-292).

2. Hansen MS, Brennum J, Moltke FB, Dahl JB. Pain treatment after craniotomy: where is the (procedurespecific) evidence? A qualitative systematic review. Eur J Anaesthesiol. 2011;28(12):821-9.

3. Vadivelu N, Mitra S, Narayan D. Recent advances in postoperative pain management

Yale J Biol Med. 2010;83(1):11-25.

4. Bigal ME, Serrano D, Reed M, Lipton RB. Chronic migraine in the population: burden, diagnosis, and satisfaction with treatment. Neurology. 2008;71:559-66.

5. Eriksen J, Jensen MK, Sjogren P, Ekholm O, Rasmussen NK. Epidemiology of chronic non-malignant pain in Demark. Pain. 2003;106:221-8.

6. Peón AU, Diccini S. Postoperative pain in craniotomy. Rev Latino-am Enfermagem. 2005;13(4):489-95.

7. Duingnan $M$, Dunn V. Perceived barriers to pain management. Emerg Nurs. 2009;16(9):31-5.

8. Lee $\mathrm{K}$, Hyunsoo $\mathrm{OH}$, Yeonk SUH, Whasook SEO. Patterns and clinical correlates of pain among brain injury patients in critical care pain observation tool. Pain Manage Nurs. 2011;1-9.

9. Taylor A, Stanbury L. A review of postoperative pain management and the challenges Current Anaesthesia Crit Care. 2009;20:188-94.

10. Ene KW, Nordberg G, Bergh I, Johansson FG, Sjostrom B. Postoperative pain management the influence of surgical ward nurses. J Clin Nurs. 2008;17(15):2042-50. 
11. Helms JE, Barone CP. Physiology and treatment of pain. Crit Care Nurse. 2008;28(6):38-49.

12. Durieux ME, Himmelseher S. Pain control after craniotomy: off balance on the tightrope?. J Neurosurg. 2007; 106(2):207-8.

13. Richards J, Hubbert AO. Experiences of expert nurses in caring for patients with postoperative pain. Pain Management Nursing. 2007;8(1):17-24.

14. World Health Organization. . Cancer pain relief with a guide to opioid availability (Second edition). Geneva: WHO; 1996.

15. Jarzyna D, Jungquist CR, Pasero C, Willens JC, Nisbet $A$, Oakes $L$, et al. American Society for Management Nursing Guidelines on Monitoring for Opiod-Induced Sedation and Respiratory Depression. Pain Manage Nurs. $2011 ; 12(3): 118-45$.

16. Nicholson B. Benefits of extended-release opioid analgesic formulations in the treatment of chronic pain. 2009;9(1):71-81.

17. Shug AS. Combination analgesia in 2005 - a rational approach: focus on paracetamol-tramadol. Clin Rheumatol. 2006;25(1):16-21.

18. Rahimi SY, AlleYne CH, Vernier E, Witcher RM, Vender JR. Postoperative pain management with tramadol after craniotomy: evaluation and cost analysis. J Neurosurg. 2010;112(2):268-72.

19. Barnes PM, Bloom B, Nahin RL. Complementary and alternative medicine use among adults and children: United States, 2007. National Health Statistics Reports. 2008;10(12):1-23.

20. Chou R, Huffman LH. Nonpharmacologic therapies for acute and chronic low back pain: a review of the evidence for an American Pain Society/American College of Physicians clinical practice guideline. Annals Internal Med. 2007;147(7):492-504. Erratum in: Annals Internal Med. 2008 Feb 5;148(3):247-8.

21. Messeri A, Abeti MS, Guidi G, Simonetti M. Pain knowledge among doctors and nurses: a survey of 4912 healhcare in Tuscany. Minerva Anestesiol. 2008;74(4):113-8.

22. Talke PO, Gelb AW. Postcraniotomy pain remains a real headache! Eur J Anaesthesiol. 2005;22:325-7.

23. Sousa FAEF, Pereira LV, Cardoso R, Hortense P. Multidimensional pain evalution scale. Rev. Latino-Am. Enfermagem. 2010;18(1):3-10.

24. Roberts SA. Central sensitization: clinical implications for chronic head and neck pain. Clin Med Diagn. $2011 ; 1(1): 1-7$.
25. Hortense P, Sousa FAEF. Developing a comparative scale of different nociceptive and neuropathic pain through two psychophysical methods. Rev. Latino-Am. Enfermagem. 2009;17(2):207-14. 